\title{
Formulation and characterization of oral rapid disintegrating tablets of levocetirizine
}

\author{
Samvedna ${ }^{1, A-D, F}$, Shammy Jindal ${ }^{1, A, B, F}$, Gaurav Mishra ${ }^{2, C-F}$, Jyotsana R. Madan ${ }^{3, C-F}$, Gaurav Gupta ${ }^{4, C-F}$, Rajendra Awasthi ${ }^{5, A-F}$, \\ Terezinha de Jesus Andreoli Pinto ${ }^{6, C-F}$, Kamal Dua ${ }^{7,(-F}$, Giriraj T. Kulkarni ${ }^{5, A, C-F}$ \\ ${ }^{1}$ Laureate Institute of Pharmacy, Jawalamukhi, India \\ ${ }^{2}$ Drug Delivery and Nanotechnology Laboratory, Bhagyoday Teerth Pharmacy College, Sagar, India \\ ${ }^{3}$ Department of Pharmaceutics, Smt. Kashibai Navale College of Pharmacy, Savitribai Phule Pune University, India \\ ${ }^{4}$ School of Pharmaceutical Sciences, Jaipur National University, Jagatpura, India \\ ${ }^{5}$ Amity Institute of Pharmacy, Amity University, Noida, India \\ ${ }^{6}$ Department of Pharmacy, Faculty of Pharmaceutical Sciences, University of São Paulo, Brazil \\ ${ }^{7}$ Discipline of Pharmacy, Graduate School of Health, University of Technology, Sydney, Australia \\ A - research concept and design; $\mathrm{B}$ - collection and/or assembly of data; $\mathrm{C}$ - data analysis and interpretation; \\ $D$ - writing the article; $E$ - critical revision of the article; $F$ - final approval of the article
}

\section{Address for correspondence \\ Rajendra Awasthi}

E-mail: awasthi02@gmail.com

Funding sources

None declared

Conflict of interest

None declared

Received on June 15, 2018

Reviewed on June 29,2018

Accepted on November 23, 2018

Cite as

Samvedna, Jindal S, Mishra G, Madan JR, Gupta G, Awasthi R, de Jesus Andreoli Pinto T, Dua K, Kulkarni GT. Formulation and characterization of oral rapid disintegrating tablets of levocetirizine. Polim Med. 2018;48(1):31-40.

doi:10.17219/pim/99951

DOI

10.17219/pim/99951

Copyright

( 2018 by Wroclaw Medical University

This is an article distributed under the terms of the

Creative Commons Attribution Non-Commercial License

(http://creativecommons.org/licenses/by-nc-nd/4.0/)

\section{Abstract}

Background. Levocetirizine, active $\mathrm{R}(-)$ enantiomer of cetirizine, is an orally active and selective $\mathrm{H1}$ receptor antagonist used medically as an anti-allergic. Allergic rhinitis is a symptomatic disorder of the nose induced by inflammation mediated by immunoglobulin $\mathrm{E}(\mathrm{lgE})$ in the membrane lining the nose after allergen exposure.

Objectives. The purpose of the present study was to prepare rapidly disintegrating tablets of levocetirizine after its complexation with $\beta$-cyclodextrin ( $\beta$-CD).

Material and methods. Levocetirizine- $\beta-C D$ complex tablets were prepared by direct compression technique using 3 synthetic superdisintegrants in different proportions. Development of the formulation in the present study was mainly based on the concentration of superdisintegrants and the properties of the drug. Nine batches of tablets were formulated and evaluated for various parameters: drug content, weight variation, water absorption ratio, wetting time, in vitro disintegration, hardness, friability, thickness uniformity, and in vitro dissolution.

Results. A Fourier-transform infrared spectroscopy (FTIR) study showed that there were no significant interactions between the drug and the excipients. The prepared tablets were good in appearance and showed acceptable results for hardness and friability. The in vitro disintegrating time of the formulated tablet batches was found to be $15-35$ s percentage and the drug content of tablets in all formulations was found to be between 90-102\%, which complied with the limits established in the United States Pharmacopeia.

Conclusions. Complexation of levocetirizine with $\beta$-CD significantly improves the solubility of the drug. The disintegration time of the tablets was decreased with an increase in superdisintegrant amount. The tablets (batch CPX5) had a minimum disintegration time of $20 \mathrm{~s}$ and $99.99 \%$ of the drug was released within $10 \mathrm{~min}$.

Key words: direct compression, superdisintegrants, $\beta$-cyclodextrin complex, rapidly disintegrating tablets 


\section{Introduction}

Tablets are the most widely accepted dosage forms. ${ }^{1,2}$ Rapidly disintegrating tablets (RDTs) are gaining more popularity as they can be administered without the need to be swallowed with water, and they are dissolved or easily disintegrated in the mouth within a few seconds. The drug is released immediately when the tablet is placed on the tongue. The RDTs are in ever-increasing demand compared to liquid dosage forms due to the ease of handling, accurate dose and good stability during storage. They improve the oral bioavailability of drugs as compared to conventional tablets. The released drug will be absorbed from the whole gastrointestinal tract and thus the oral bioavailability will improve. ${ }^{3}$ The disintegration time for orally rapid disintegrating tablets is generally considered to be less than $60 \mathrm{~s} .{ }^{4,5}$ Various RDTs have been reported to improve patient compliance and bioavailability, such as dispersible tablets, rapidly disintegrating tablets, orally disintegrating tablets, quick disintegrating tablets, rapid dissolving tablets, porous tablets, quick melt tablets, etc. ${ }^{6}$

Rapidly disintegrating drug delivery systems (RDDDS) offer several benefits such as easy administration to children and elderly patients having difficulties swallowing (dysphagia) and in the case of tremors or mental retardation condition. ${ }^{7}$ The RDDDS are also useful for local action such as a local anesthetic for toothaches, oral ulcers, cold sores, or teething. ${ }^{8}$ The RDTs can be prepared using conventional methods like direct compression, wet granulation, moulding, spray drying, freeze-drying, and sublimation. Proper choice of superdisintegrants and consistency in its performance are of critical importance to the formulation development of RDTs. ${ }^{9}$ Examples of some widely used superdisintegrants are modified starch (sodium starch glycolate), modified cellulose (croscarmellose) and cross-linked polyvinylpyrrolidone (crospovidone).${ }^{10}$

Basic considerations in formulating RDTs are palatability, aqueous solubility, hygroscopicity, and mechanical strength. ${ }^{11}$ These systems are made to disintegrate or dissolve in the oral cavity, which may lead to the sensation of taste. Thus, taste masking of the bitter drugs becomes critical to patient compliance. Water solubility is another critical parameter that needs to be examined carefully during the manufacturing of RDTs. The formation of a eutectic mixture of most of the BCS (biopharmaceutical classification system) class I and III drugs leads to a depression in freezing point. This results in the formation of a glassy solid mass which can be easily sublimated with drying. Drying of the formed glassy solid mass may cause it to collapse due to the loss of supporting structures. ${ }^{12}$ Normal storage conditions may affect the physical integrity of RDTs, hence specialized packaging is needed to protect them from environmental conditions such as temperature and humidity. For rapid disintegration, RDTs are manufactured at low compression force. This may lead to the formation of a friable or brittle tablet. The handling of such products might be difficult and requires peel-off blister packing. The objective of compressed-tablet manufactures is to deliver the orally correct amount of the drug in proper time and to the desired location while subsequently maintaining its chemical integrity to that point. The aim of the present study was to prepare RDTs of levocetirizine to improve the drug stability and its therapeutic benefits.

\section{Material}

The levocetirizine was a generous gift from Cipla Ltd., Ahmedabad, India. $\beta$-cyclodextrin $(\beta-C D)$ was purchased from Central Drug House (P) Ltd., New Delhi, India. Sodium starch glycolate (SSG), croscarmellose sodium (CMS), microcrystalline cellulose (MCC), crospovidone (CP), magnesium stearate, aerosol, and mannitol were purchased from S.D. Fine Chem Ltd., Mumbai, India. All the chemicals used were of analytical grade.

\section{Methods}

\section{Preparation of levocetirizine- $\beta-C D$ complex}

Levocetirizine- $\beta$-CD complex (1:1 molar ratio) was prepared using the kneading method. Briefly, an accurately weighed amount of the pure drug and $\beta-C D$ was triturated in a clean and dry mortar with a small volume of the watermethanol solvent system to make a thick slurry. The mass was uniformly mixed and dried at $40^{\circ} \mathrm{C}$. The dried mass was grained and sifted through a mesh (100). ${ }^{12-15}$

\section{Characterization of levocetirizine- $\beta-C D$ complex}

\section{UV spectroscopic study}

The confirmation of complexation between the levocetirizine $-\beta-C D$ was carried out by ultraviolet-visible spectrophotometrically (UV-visible spectrophotometer, $3000^{+}$, LabIndia, Mumbai, India). Pure levocetirizine $(10 \mathrm{mg})$ was dissolved in methanol $(100 \mathrm{~mL})$, filtered and analyzed at $231 \mathrm{~nm}$ after suitable dilution. Similarly, the same spectrum was taken for the levocetirizine- $\beta-C D$ complex (containing $10 \mathrm{mg}$ levocetrizine) at $233 \mathrm{~nm}$. The change in absorbance of the drug in levocetirizine $-\beta-C D$ complex was recorded.

\section{Fourier-transform infrared spectroscopy}

A Fourier-transform infrared (FTIR) spectroscopy of pure levocetirizine, $\beta-C D$ and levocetirizine- $\beta-C D$ complex (1:1) was carried out by the FTIR peak match- 
ing method (IR-affinity-1; Shimadzu, Kyoto, Japan). Briefly, the samples were mixed with dried potassium bromide $(\mathrm{KBr})$ and compressed into a pellet using $\mathrm{KBr}$ press at $10 \mathrm{t}$. The pellets were scanned from $4000-400 \mathrm{~cm}^{-1}$ at $4 \mathrm{~cm}^{-1}$ resolution. The complex formation was evaluated by comparing the FTIR spectra of the drug- $\beta-C D$ complex and that of the pure drug. ${ }^{16,17}$

\section{X-ray diffraction studies}

An X-ray diffraction study of pure levocetirizine and the drug- $\beta$-CD complex (1:1) was done by X-ray powder diffractometer (PW 3040/60 Xpert PRO; PANalytical, Almelo, the Netherlands) using $\mathrm{Cu} \mathrm{K \alpha}$ radiations $(\lambda=1.5405980 \AA)$ ), $40 \mathrm{~mA}$ current and $40 \mathrm{kV}$ voltage. The samples were analyzed over 0-80 $2 \theta$ range with a scan step size of $2^{\circ} / \mathrm{min} .^{18}$

\section{Powder characterization}

\section{Determination of angle of repose}

The angle of repose was determined to know the flow properties of granules using the funnel method. Briefly, the powder mix was allowed to pour from a funnel that can be raised vertically until a maximum cone height was obtained. The angle of repose $(\theta)$ was determined by measuring the height $(\mathrm{h})$ and radius $(\mathrm{r})$ of the cone using the following formula ${ }^{19}$ :

$$
\tan \theta=\frac{\mathrm{h}}{\mathrm{r}}
$$

The mean result of triplicate measurements and the standard deviation (SD) were reported.

\section{Determination of loose density}

Loose bulk density (LBD) is the ratio of powder weight in grams to the loose bulk volume $\left[\mathrm{cm}^{3}\right]$. A sample $(5 \mathrm{~g})$ was carefully introduced in a $10 \mathrm{~mL}$ graduated measuring cylinder and LBD was determined using the following formula ${ }^{19}$ :

$$
\text { loose bulk density }=\frac{\text { weight of powder }[\mathrm{g}]}{\text { bulk volume }\left[\mathrm{cm}^{3}\right]}
$$

The mean result of triplicate measurements and the SD were reported.

\section{Determination of tapped density}

For the determination of tapped density, a powder sample $(5 \mathrm{~g})$ was introduced in a $10 \mathrm{~mL}$ graduated measuring cylinder. The cylinder was dropped onto a flat surface 50 times from $2.5 \mathrm{~cm}$ height. Tapped bulk density was determined by applying the following formula ${ }^{19}$ :

$$
\text { tapped density }=\frac{\text { weight of powder }}{\text { tapped volume of powder }}
$$

The mean result of triplicate measurements and the SD were reported.

\section{Determination of the Hausner ratio}

Hausner ratio $(\mathrm{HR})$ is an indirect index of ease of powder flow. Lower HR $(<1.25)$ indicates better flow properties. It was determined by applying the following formula ${ }^{19}$ :

$$
\text { Hausner ratio }=\frac{\text { tapped density }}{\text { bulk density }}
$$

The mean result of triplicate measurements and the SD were reported.

\section{Determination of void volume}

The volume of the space between particles was determined by applying the following formula:

$$
\text { void volume }=\text { bulk volume }- \text { tapped volume }
$$

The mean result of triplicate measurements and the SD were reported.

\section{Determination of Carr's compressibility index}

Carr's compressibility index is determined using density measurements. A particle bed having more compressibility is less flowable and vice versa. Carr's compressibility index [\%] was determined by the following formula ${ }^{19}$ :

$$
\text { Carr's index }=\frac{\text { tapped density }- \text { bulk density }}{\text { tapped density }} \times 100
$$

The mean result of triplicate measurements and the SD were reported.

\section{Determination of percentage porosity}

The percent porosity of the granules of each prepared batch was determined using the following formula:

$$
\text { porosity [\%] }=1-\frac{\mathrm{V}_{\mathrm{p}}}{\mathrm{V}_{\mathrm{b}}} \times 100
$$

Where $\mathrm{V}_{\mathrm{b}}$ is the bulk volume, and $\mathrm{V}_{\mathrm{p}}$ is the particle volume. The mean result of triplicate measurements and the SD were reported. 


\section{Preparation and evaluation of rapidly disintegrating tablets}

Rapidly disintegrating tablets of levocetirizine were prepared by direct compression method. Croscarmellose sodium (CCS), sodium starch glycolate (SSG) and crospovidone $(C P)$ were used as superdisintegrants. The $\beta-C D$ was used as a complexing agent to improve the dissolution of the drug. Microcrystalline cellulose (MCC) was used as a binder (Table 1 ). Drug- $\beta$-CD complex equivalent to $5 \mathrm{mg}$ of the levocetirizine and all the excipients except magnesium stearate and aerosil were taken in a mortar and mixed. The powder mix was passed through a 80 sieve. Lubrication was done using magnesium stearate and aerosil. The final blend was compressed into caplets using a 10-station compression machine (Minipress-1, Karnavati, Ahmedabad, India) to produce $120 \mathrm{mg}$ tablets using $4 \mathrm{~mm}$ diameter die and punches. ${ }^{20}$

The prepared tablets were evaluated for both non-official and official tests. Tablets from each batch were subjected to the following tests.

\section{General appearance}

The general appearance of a tablet, its visual identity and overall elegance is essential for patient's acceptance. The tablet's shape, size, color, presence or absence of an odor, and legibility of any identifying marking were studied as the general appearance characteristics.

\section{Test for weight uniformity}

The United States Pharmacopeia (USP) procedure for the determination of uniformity of tablet weight was followed. Twenty tablets from each batch were taken and weighed individually and collectively on a digital weighing balance (MAB 182; Wensar, Mumbai, India). The average weight of 20 tablets was calculated. The weight variation was calculated for USP limits, i.e., for an average weight of $80 \mathrm{mg}$ or less, $80-250 \mathrm{mg}$ and more than $250 \mathrm{mg}$; the maximum percentage differences allowed are $10 \%$, $7.5 \%$ and $5 \%$, respectively. The mean result of triplicate measurements and the SD were reported. ${ }^{21}$

\section{Determination of tablet thickness}

The thickness of tablets was determined using vernier callipers. Twenty tablets from each batch were randomly selected for thickness measurements. The mean result of triplicate measurements and the SD were reported.

\section{Determination of tablet hardness}

The resistance of tablets to chipping, abrasion or breakage under the conditions of storage, transformation and handling depends on its hardness. The tablet hardness was determined by diametral compression using a dialtype Monsanto tablet hardness tester. A tablet hardness of about $4-5 \mathrm{~kg} / \mathrm{cm}^{2}$ is considered adequate for mechanical stability. The sampling was carried out in triplicate for each batch.

\section{In vitro disintegration, dispersion and wetting test}

One tablet was placed in each tube of a USP tablet disintegration test apparatus (ED-2 SAPO; Electrolab, Mumbai, India) and the basket rack was positioned in a $1 \mathrm{~L}$ beaker containing freshly prepared and cooled distilled water at $37 \pm 0.5^{\circ} \mathrm{C}$. The time required for a complete disintegration of the tablet with no palpable mass remaining in the apparatus was measured. Dispersion time of the tablet was recorded by placing 1 tablet from each batch in a Petri dish containing phosphate buffer ( $\mathrm{pH}$ 6.8). For the determination of the wetting time of the tablet, a circular piece of tissue paper $(12 \times 10.75 \mathrm{~cm})$ folded twice was placed in a small Petri dish (internal diameter $6.5 \mathrm{~cm}$ ) containing $10 \mathrm{~mL}$ of phosphate buffer ( $\mathrm{pH}$ 6.8). A tablet was placed on the paper, and the time for complete wetting was measured. The sampling was carried out in triplicate for each batch. ${ }^{22}$

\begin{tabular}{|c|c|c|c|c|c|c|c|c|c|}
\hline \multirow[b]{2}{*}{ Ingredients } & \multicolumn{9}{|c|}{ Formulation code } \\
\hline & $\begin{array}{l}\mathrm{CPX}_{1} \\
{[\mathrm{mg}]}\end{array}$ & $\begin{array}{l}\mathrm{CPX}_{2} \\
{[\mathrm{mg}]}\end{array}$ & $\begin{array}{l}\mathrm{CPX}_{3} \\
{[\mathrm{mg}]}\end{array}$ & $\begin{array}{l}\mathrm{CPX}_{4} \\
{[\mathrm{mg}]}\end{array}$ & $\begin{array}{l}\mathrm{CPX}_{5} \\
{[\mathrm{mg}]}\end{array}$ & $\begin{array}{l}\mathrm{CPX}_{6} \\
{[\mathrm{mg}]}\end{array}$ & $\begin{array}{l}\mathrm{CPX}_{7} \\
{[\mathrm{mg}]}\end{array}$ & $\begin{array}{l}\mathrm{CPX}_{8} \\
{[\mathrm{mg}]}\end{array}$ & $\begin{array}{l}\mathrm{CPX}_{9} \\
{[\mathrm{mg}]}\end{array}$ \\
\hline Levocetirizine- $\beta$-CD complex* & 14.5 & 14.5 & 14.5 & 14.5 & 14.5 & 14.5 & 14.5 & 14.5 & 14.5 \\
\hline SSG & - & - & 10 & 11 & 12 & - & - & 10 & - \\
\hline CMS & 11 & - & - & - & - & 10 & 11 & - & - \\
\hline$C P$ & - & 10 & - & - & - & - & - & - & 10 \\
\hline Mg stearate & 3 & 2 & 3 & 2 & 2 & 3 & 1 & 2 & 1 \\
\hline Aerosil & 2 & 2 & 2 & 2 & 2 & 2 & 2 & 2 & 2 \\
\hline Mannitol & 21.5 & 18.5 & 18.5 & 20 & 14.5 & 14.5 & 22 & 16.5 & 12.5 \\
\hline MCC & 68 & 73 & 72 & 70 & 75 & 76 & 74 & 75 & 80 \\
\hline
\end{tabular}

* Complex equivalent to 5 mg of levocetirizine; $\beta$-CD - $\beta$-cyclodextrin; SSG - sodium starch glycolate; CMS - croscarmellose sodium; CP - crospovidone; MCC - microcrystalline cellulose. 


\section{Determination of water absorption ratio}

For the determination of water absorption ratio, a small piece of tissue paper (folded twice) was placed in a Petri dish containing distilled water $(6 \mathrm{~mL})$. The tablet was placed on the wet paper and the weight of the wet tablet was recorded. The water absorption ratio $(R)$ was calculated using the following formulation ${ }^{22}$ :

$$
\mathrm{R}=\frac{\mathrm{Wa}-\mathrm{Wb}}{\mathrm{Wb}} \times 100
$$

where $\mathrm{Wb}$ and $\mathrm{Wa}$ are the weight of the tablet before and after water absorption, respectively. The mean result of triplicate measurements and the SD were reported.

\section{Determination of percentage friability}

A USP tablet friabilator (EF-2; Electrolab, Mumbai, India) was employed for the determination of tablet friability. Pre-weighted tablets (20 tablets) were placed in the friabilator. The friabilator was rotated for $4 \mathrm{~min}$ at $25 \mathrm{rpm}$. At the end of the test, the tablets were dusted and re-weighed. The loss in tablet weight was measured and the friability was calculated using the following formula:

$$
\text { friability [\%] }=\frac{\text { weight after } 100 \text { counts }}{\text { initial weight }} \times 100
$$

\section{Determination of drug content}

Ten tablets of levocetirizine from each batch were crushed and the mass equivalent to 1 tablet was taken and transferred to a $100 \mathrm{~mL}$ volumetric flask. Final volume was adjusted with phosphate buffer ( $\mathrm{pH}$ 6.8). The mixture was shaken for $30 \mathrm{~min}$ in a water bath shaker incubator. The mixture was filtered and the filtrate was analyzed at $233.00 \mathrm{~nm}$ after suitable dilutions using an ultravioletvisible spectrophotometer $\left(3000^{+}\right.$; Labindia, Mumbai, India). The mean result of triplicate measurements and the SD were reported. ${ }^{23}$

\section{X-ray diffraction study}

X-ray diffraction study of the prepared tablet (formulation CPX5) was carried out similarly as for the pure drug and complex.

\section{In vitro dissolution studies}

An in vitro dissolution study was carried out using USP tablet dissolution test apparatus II (DS 8000; Labindia, Mumbai, India) at $50 \mathrm{rpm}$ in $900 \mathrm{~mL}$ of phosphate buffer (pH 6.8). The temperature was maintained at $37 \pm 0.5^{\circ} \mathrm{C}$. The samples were withdrawn at predetermined time in- tervals of $0 \mathrm{~min}, 2 \mathrm{~min}, 4 \mathrm{~min}, 6 \mathrm{~min}$, and $10 \mathrm{~min}$. Aliquots $(5 \mathrm{~mL})$ were withdrawn, filtered and analyzed spectrophotometrically using a UV spectrophotometer $\left(3000^{+}\right)$ at $233 \mathrm{~nm}$. Complete sink condition was maintained by adding an equal amount of fresh dissolution medium $\left(37 \pm 0.5^{\circ} \mathrm{C}\right)$ after each sampling. The sampling study was carried out in triplicate for each batch. The kinetic study of drug release data was done by zero order (cumulative percentage drug released vs time) and first order (percentage drug retained vs time) plots.

\section{Results and discussion}

\section{Characterization of levocetirizine- $\beta-C D$ complex}

\section{UV spectroscopic study}

The results showed no shift in the $\lambda_{\max }$ of levocetirizine in the presence of $\beta$-CD complex (Fig. 1). The slight change in absorbance could be explained due to the changes in the solvent microenvironment and the transfer of the guest molecule of water in the $\beta-C D$ cavity during complex formation.

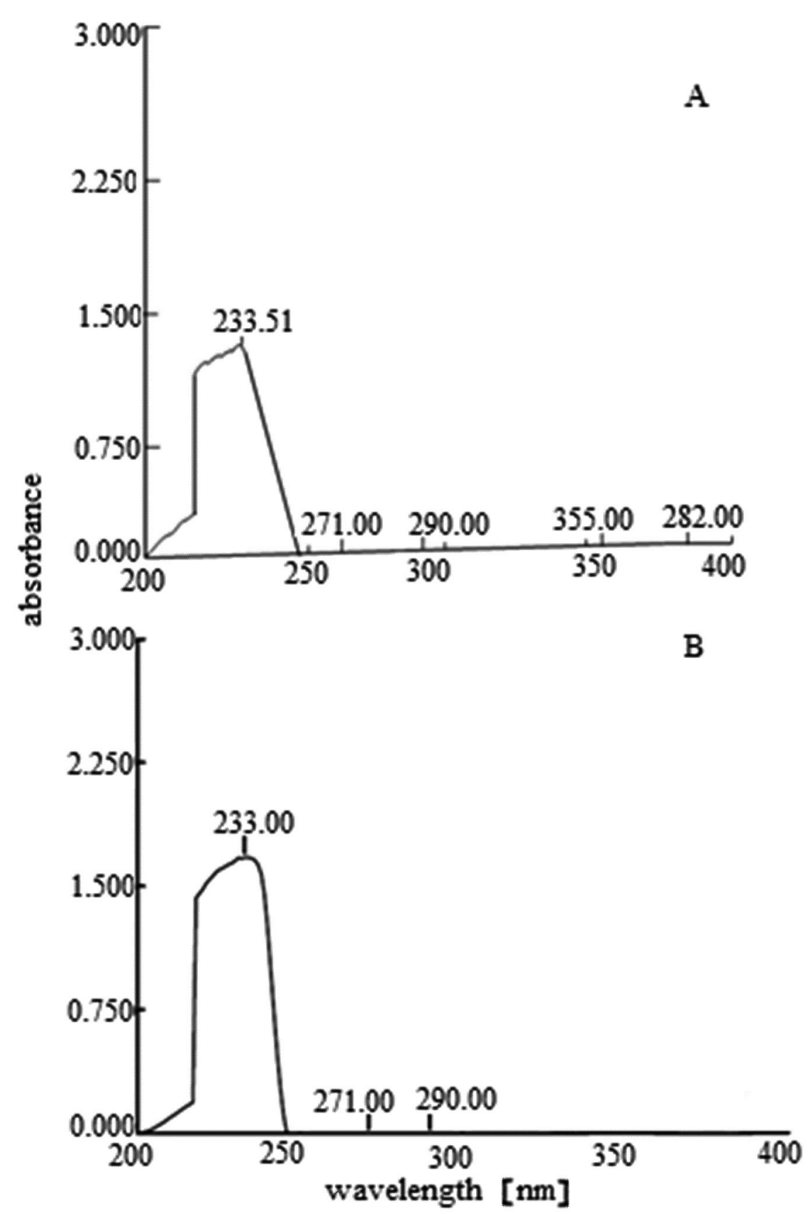

Fig. 1. UV scan spectrum of the levocetirizine- $\beta$-cyclodextrin ( $\beta-C D)$ complex (A) and pure levocetirizine (B) 


\section{Fourier-transform infrared spectroscopy}

A FTIR spectroscopy was carried out to investigate the possible interaction between levocetirizine and $\beta-C D$, if any. The FTIR spectrum of levocetirizine, $\beta-C D$ and physical mixture of levocetirizine- $\beta-C D$ complex are illustrated in Fig. 2. The chemical interaction between the levocetirizine$\beta-C D$ leads to identifiable changes in the infrared profile of dispersion. In the present study, the FTIR spectrum of levocetirizine showed characteristic peaks at $3641 \mathrm{~cm}^{-1}(\mathrm{OH}$ stretching), $2785 \mathrm{~cm}^{-1}\left(\mathrm{CH}_{2}\right.$ stretching), $1718 \mathrm{~cm}^{-1}$ (stretching of ester carbonyl and $-\mathrm{COOH}$ groups), $1602 \mathrm{~cm}^{-1}(\mathrm{C}=\mathrm{C})$, $1479 \mathrm{~cm}^{-1}$ (ether group), $1319 \mathrm{~cm}^{-1}$ (C-N stretching), $1085 \mathrm{~cm}^{-1}$ ( $\mathrm{C}=\mathrm{O}$ stretching), and $721 \mathrm{~cm}^{-1}$ (C-Cl stretching). In the case of $\beta-C D$, stretching (broad) of the $\mathrm{O}-\mathrm{H}$ group was observed near $3227 \mathrm{~cm}^{-1}$. $\beta$-CD showed characteristic peaks near $2928 \mathrm{~cm}^{-1}$ (antisymmetric and symmetric stretching of $-\mathrm{CH}_{2}$ group), $1642 \mathrm{~cm}^{-1}(\mathrm{O}-\mathrm{C}$ (2-bands) $\mathrm{C}=\mathrm{O}$ (amide I band)), $1410 \mathrm{~cm}^{-1}$ (in plane bending) of $\mathrm{OH}$, bending of $\alpha-\mathrm{CH}_{2}$ and deformation of $\left.\mathrm{CH}_{2}\right), 1332 \mathrm{~cm}^{-1}$ in plane bending of $\mathrm{OH}$ ), $1152 \mathrm{~cm}^{-1}$ (bending of $\mathrm{C}-\mathrm{C}-\mathrm{C}$ ), $1077 \mathrm{~cm}^{-1}$

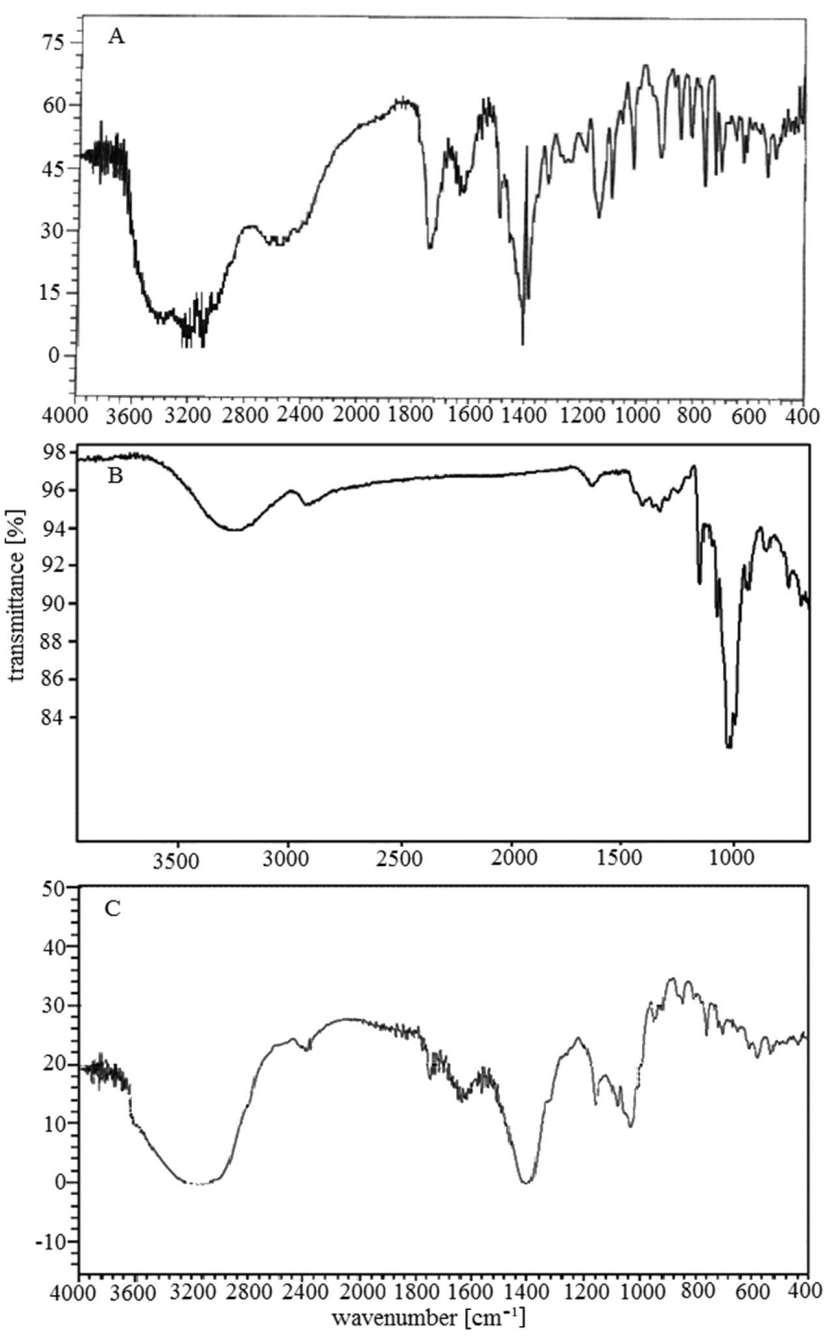

Fig. 2. Fourier-transform infrared spectroscopy (FTIR) spectrum of levocetirizine $(A), \beta$-cyclodextrin ( $\beta-C D)(B)$ and physical mixture of levocetirizine- $\beta$-cyclodextrin ( $\beta$-CD) complex (C) and $1022 \mathrm{~cm}^{-1}(\mathrm{O}-\mathrm{H}$ (H-bonded), usually broad $\mathrm{C}-\mathrm{O})$, $937 \mathrm{~cm}^{-1}, 860 \mathrm{~cm}^{-1}$ and $753 \mathrm{~cm}^{-1}$ (stretching of $=\mathrm{C}-\mathrm{H}$ and $=\mathrm{CH}_{2}$, bending and ring puckering of $\mathrm{C}-\mathrm{H}$ ) and $703 \mathrm{~cm}^{-1}$ (cis-RCH=CHR). The ester carbonyl stretching bend of levocetirizine shifted from $1718 \mathrm{~cm}^{-1}$ down to $1675 \mathrm{~cm}^{-1}$. This may be due to the intermolecular hydrogen bonding between levocetirizine and $\beta-C D$. The peak due to the stretching vibration of the $\mathrm{N}-\mathrm{H}$ bond near $3317 \mathrm{~cm}^{-1}$ in the dihydropyridine ring was broadened, nearly disappeared in complex spectra. A broad peak near $3227 \mathrm{~cm}^{-1}$ (-OH band of pure $\beta-C D)$ was observed in the spectrum of the complex, indicating complex formation and inclusion of levocetirizine in the cavity of $\beta$-CD. The increment in intensity is due to the insertion of a benzene ring into the electron-rich cavity of $\beta-C D$, which increases electron density and leads to the increase in frequency. Thus, the FTIR spectrum proves the formation of the levocetirizine- $\beta-C D$ complex.

\section{X-ray diffraction}

An X-ray diffraction study was used to evaluate the physical state of pure levocetirizine and the drug within the levocetirizine- $\beta$-CD complex $(1: 1)$. The X-ray diffractograms of pure levocetirizine and levocetirizine $-\beta-C D$ complex are presented in Fig. 3. Levocetirizine has shown characteristic intense peaks at $2 \theta$ of $5.50,6.50,7.50,8.32$, $10.58,12.42,13.54,14.51,15.21,16.03,16.94,17.87,18.98$, $19.20,20.81,21.54,22.64,23.84,24.58,25.24,25.64,26.23$, 27.64, 29.00, 29.94, 30.32, 31.11, 31.75, 33.34, 35.51, 35.85, $36.35,37.94$, and 39.21 because of its crystalline state. In the levocetirizine- $\beta$-CD complex, the drug peaks are visible at $2 \theta$ of $4.78,6.54,7.33,7.68,8.27,9.27,9.98,10.93$,

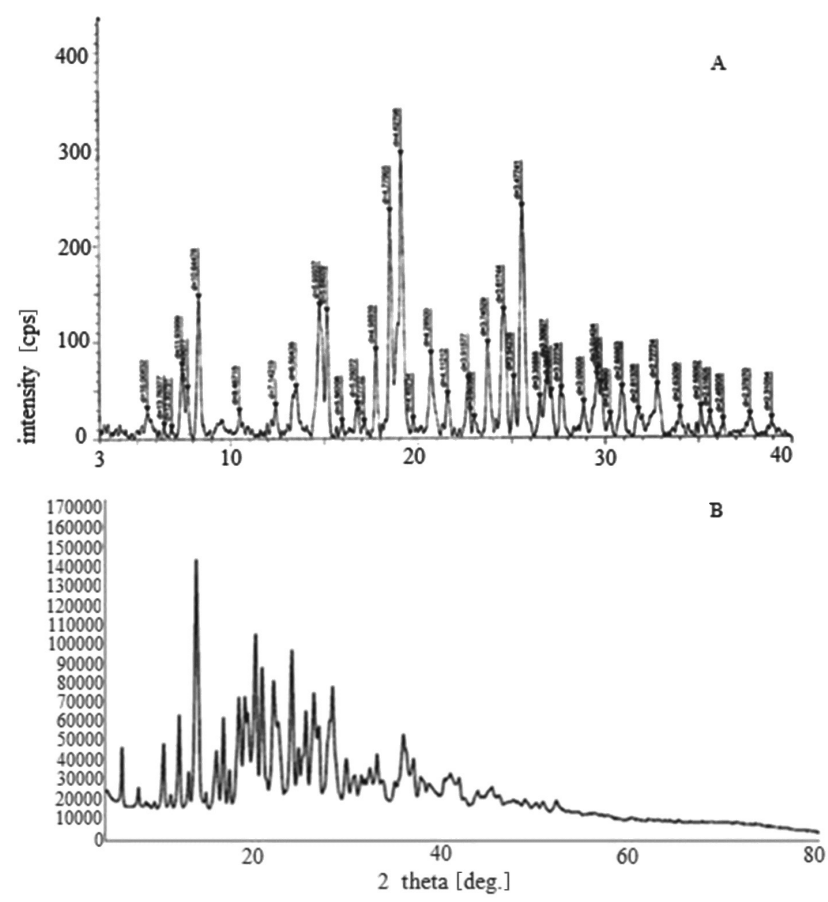

Fig. 3. X-ray diffraction patterns of pure levocetirizine (A) and levocetirizine- $\beta$-cyclodextrin ( $\beta$-CD) complex (1:1) (B) 
$12.742,13.06,14.90,15.67,16.32,17.34,18.30,19.12$, 19.80, 21.03, 23.10, 24.57, 25.38, 26.85, 27.36, 29.71, 30.47, $31.40,32.18,34.03,35.03,36.12,37.69,40.02,41.03$, and 44.53 , indicating the crystalline form of the drug within the complex. The drug is not in amorphous form, otherwise the drug peaks would have disappeared completely in the complex. However, the crystallinity of the drug has been decreased in the case of the levocetirizine- $\beta-C D$ complex as some of the peaks disappeared.

\section{Evaluation of powder}

\section{Angle of repose}

The angle of repose $(\theta)$ was calculated to know the flow properties of granules. Based on the particle size, powders are broadly classified as very fine, fine, moderately fine, moderately coarse, and coarse. The particles having size $<100 \mathrm{~mm}$ tend to be more cohesive and less free-flowing. Larger particles have good flow properties. The cohesivity of powder decreases with the increase in particle size. The USP defined the range of angle of repose as: $25-30$ for excellent flow, 31-35 for good, 36-40 for fair, 41-45 for passable, 46-55 for poor flow, 56-65 for very poor flow, and $>66$ for considerably poor flow. ${ }^{24}$ In the present study, the value of angle of repose for all the batches ranged between $23.93 \pm 0.22$ to $30.04 \pm 0.23$ (Table 2), indicating excellent flow potential of the blend. The powdered mass of the different formulations was found to be non-aggregating. The results are acceptable for tablet manufacturing purposes.

\section{Bulk density}

The results of bulk density are represented in Table 2 . The bulk densities of all the batches were observed between
$0.45 \pm 0.27 \mathrm{~g} / \mathrm{cm}^{3}$ and $0.56 \pm 0.38 \mathrm{~g} / \mathrm{cm}^{3}$. The bulk density of batches $\mathrm{CPX}_{1}$ and $\mathrm{CPX}_{6}$ was found to be almost similar, indicating similar bulk volume and packing arrangements.

\section{Tapped density}

The results of tapped density are represented in Table 2. The tapped density was observed between $0.54 \pm 0.32 \mathrm{~g} / \mathrm{mL}$ and $0.69 \pm 0.28 \mathrm{~g} / \mathrm{mL}$. The difference in the values of bulk density and tapped density indicates very little or no change in powder volume even after 50 tappings.

\section{Hausner ratio}

The HR is an indication of flow properties of the powder blend. A HR $<1.25$ indicates good flow properties, $1.25-1.50$ indicates poor but improvable, and $>1.50$ indicates poor flowability of the powder. ${ }^{24}$ The results show that the HR of all the formulations was in the range from $1.03 \pm 0.02$ to $1.32 \pm 0.22$ (Table 2), which indicates good flow properties of powder blends.

\section{Void volume}

The void volume was found in the range from $0.3 \pm 0.18$ to $2.4 \pm 0.39$ (Table 2), indicating that the powder blend had good flow properties.

\section{Evaluation of rapidly disintegrating tablets}

\section{General appearance}

All the tablets were white to off-white in color, round and flat in shape with a score line through the center, and had a smooth surface.

Table 2. Micrometric properties of powder blend

\begin{tabular}{|c|c|c|c|c|c|c|c|c|c|}
\hline \multirow{2}{*}{ Micrometric property } & \multicolumn{9}{|c|}{ Formulation code } \\
\hline & $\mathrm{CPX}_{1}$ & $\mathrm{CPX}_{2}$ & $\mathrm{CPX}_{3}$ & $\mathrm{CPX}_{4}$ & $\mathrm{CPX}_{5}$ & $\mathrm{CPX}_{6}$ & $\mathrm{CPX}_{7}$ & $\mathrm{CPX}_{8}$ & $\mathrm{CPX}_{9}$ \\
\hline $\begin{array}{l}\text { Angle of repose } \\
{[\theta]}\end{array}$ & $\begin{array}{l}23.93 \\
\pm 0.22\end{array}$ & $\begin{array}{l}30.04 \\
\pm 0.23\end{array}$ & $\begin{array}{l}26.68 \\
\pm 0.16\end{array}$ & $\begin{array}{l}24.93 \\
\pm 0.2\end{array}$ & $\begin{array}{l}25.63 \\
\pm 0.56\end{array}$ & $\begin{array}{l}28.93 \\
\pm 0.12\end{array}$ & $\begin{array}{l}25.40 \\
\pm 0.17\end{array}$ & $\begin{array}{l}27.00 \\
\pm 0.16\end{array}$ & $\begin{array}{l}29.83 \\
\pm 0.18\end{array}$ \\
\hline $\begin{array}{l}\text { Bulk density } \\
{[\mathrm{g} / \mathrm{mL}]}\end{array}$ & $\begin{array}{c}0.56 \\
\pm 0.38\end{array}$ & $\begin{array}{c}0.53 \\
\pm 0.34\end{array}$ & $\begin{array}{c}0.47 \\
\pm 0.65\end{array}$ & $\begin{array}{c}0.49 \\
\pm 0.12\end{array}$ & $\begin{array}{c}0.54 \\
\pm 0.21\end{array}$ & $\begin{array}{l}0.52 \\
\pm 0.3\end{array}$ & $\begin{array}{l}0.53 \\
\pm 0.2\end{array}$ & $\begin{array}{c}0.45 \\
\pm 0.27\end{array}$ & $\begin{array}{c}0.47 \\
\pm 0.22\end{array}$ \\
\hline $\begin{array}{l}\text { Tapped density } \\
{[\mathrm{g} / \mathrm{mL}]}\end{array}$ & $\begin{array}{c}0.58 \\
\pm 0.23\end{array}$ & $\begin{array}{c}0.59 \\
\pm 0.37\end{array}$ & $\begin{array}{c}0.66 \\
\pm 0.30\end{array}$ & $\begin{array}{c}0.63 \\
\pm 0.18\end{array}$ & $\begin{array}{c}0.62 \\
\pm 0.18\end{array}$ & $\begin{array}{c}0.69 \\
\pm 0.28\end{array}$ & $\begin{array}{c}0.61 \\
\pm 0.50\end{array}$ & $\begin{array}{c}0.59 \\
\pm 0.41\end{array}$ & $\begin{array}{c}0.54 \\
\pm 0.32\end{array}$ \\
\hline Void volume & $\begin{array}{c}0.30 \\
\pm 0.18\end{array}$ & $\begin{array}{r}1.10 \\
\pm 0.28\end{array}$ & $\begin{array}{c}2.90 \\
\pm 0.39\end{array}$ & $\begin{array}{c}2.20 \\
\pm 0.43\end{array}$ & $\begin{array}{c}1.10 \\
\pm 0.19\end{array}$ & $\begin{array}{c}2.40 \\
\pm 0.31\end{array}$ & $\begin{array}{r}1.20 \\
\pm 0.22\end{array}$ & $\begin{array}{c}2.40 \\
\pm 0.31\end{array}$ & $\begin{array}{r}1.50 \\
\pm 0.25\end{array}$ \\
\hline Hausner ratio & $\begin{array}{c}1.03 \\
\pm 0.02\end{array}$ & $\begin{array}{c}1.13 \\
\pm 0.17\end{array}$ & $\begin{array}{c}1.30 \\
\pm 0.78\end{array}$ & $\begin{array}{c}1.22 \\
\pm 0.18\end{array}$ & $\begin{array}{c}1.12 \\
\pm 0.18\end{array}$ & $\begin{array}{r}1.32 \\
\pm 0.22\end{array}$ & $\begin{array}{c}1.13 \\
\pm 0.29\end{array}$ & $\begin{array}{c}1.21 \\
\pm 0.50\end{array}$ & $\begin{array}{r}1.18 \\
\pm 0.28\end{array}$ \\
\hline $\begin{array}{l}\text { Porosity } \\
{[\%]}\end{array}$ & $\begin{array}{c}3.37 \\
\pm 0.05\end{array}$ & $\begin{array}{l}11.50 \\
\pm 0.28\end{array}$ & $\begin{array}{l}27.60 \\
\pm 0.42\end{array}$ & $\begin{array}{l}21.70 \\
\pm 0.29\end{array}$ & $\begin{array}{l}11.90 \\
\pm 0.42\end{array}$ & $\begin{array}{l}25.00 \\
\pm 0.12\end{array}$ & $\begin{array}{r}12.70 \\
\pm 0.08\end{array}$ & $\begin{array}{l}22.00 \\
\pm 0.12\end{array}$ & $\begin{array}{r}14.00 \\
\pm 0.16\end{array}$ \\
\hline $\begin{array}{l}\text { Carr's compressibility } \\
\text { index [\%] }\end{array}$ & $\begin{array}{l}13.44 \\
\pm 0.29\end{array}$ & $\begin{array}{l}12.60 \\
\pm 0.39\end{array}$ & $\begin{array}{l}21.69 \\
\pm 0.27\end{array}$ & $\begin{array}{l}22.22 \\
\pm 0.19\end{array}$ & $\begin{array}{l}12.47 \\
\pm 0.19\end{array}$ & $\begin{array}{l}24.63 \\
\pm 0.17\end{array}$ & $\begin{array}{r}12.80 \\
\pm 0.52\end{array}$ & $\begin{array}{l}22.24 \\
\pm 0.25\end{array}$ & $\begin{array}{r}14.80 \\
\pm 0.21\end{array}$ \\
\hline $\begin{array}{l}\text { Drug content } \\
{[\%]}\end{array}$ & $\begin{array}{l}90.63 \\
\pm 0.17\end{array}$ & $\begin{array}{l}90.01 \\
\pm 0.34\end{array}$ & $\begin{array}{l}97.07 \\
\pm 0.75\end{array}$ & $\begin{array}{l}99.76 \\
\pm 0.87\end{array}$ & $\begin{array}{c}102.09 \\
\pm 0.67\end{array}$ & $\begin{array}{l}90.06 \\
\pm 0.16\end{array}$ & $\begin{array}{l}90.78 \\
\pm 0.32\end{array}$ & $\begin{array}{l}97.57 \\
\pm 0.43\end{array}$ & $\begin{array}{l}90.76 \\
\pm 0.35\end{array}$ \\
\hline
\end{tabular}

Data presented as mean \pm standard deviation (SD); $\mathrm{n}=3$. 


\section{Uniformity of weight}

Twenty tablets were randomly selected from each batch for weight variation testing. The tablets were weighed individually and the average weight of 20 tablets was calculated. The results were within the range from $198.40 \pm 0.01 \mathrm{mg}$ to $200.41 \pm 0.12 \mathrm{mg}$ (Table 3 ). The results were within the acceptable limit given in the USP. ${ }^{24}$

\section{Thickness}

The thickness of the prepared tablets was found in the range from $2.0 \pm 0.56 \mathrm{~mm}$ to $2.99 \pm 0.05 \mathrm{~mm}$ (Table 3).

\section{Hardness}

Tablet strength and disintegrating time depend on its hardness. It had been observed that the RDTs are less hard than conventional tablets because less compression force is applied. The hardness of the prepared tablets was in the range from $2.30 \pm 0.40 \mathrm{~kg} / \mathrm{cm}^{2}$ to $3.90 \pm 0.06 \mathrm{~kg} / \mathrm{cm}^{2}$, which is sufficient to maintain the tablet integrity during storage and handling and also within the range ensuring rapid disintegration (Table 3 ).

\section{In vitro disintegrating and wetting time}

The in vitro tablet disintegration time is the time taken to undergo complete disintegration of the tablet in USP tablet disintegration apparatus under specified conditions. Disintegrating time is related to the nature and concentration of superdisintegrants and hardness of the tablet. It allows breaking the tablet into small fragments upon contact with dissolution media. The in vitro disintegrating time of the prepared tablets was found to be between $15 \mathrm{~s}$ and $35 \mathrm{~s}$. Formulations $\mathrm{CPX}_{4}$ and $\mathrm{CPX}_{5}$ had better disintegrating time, i.e., $19 \mathrm{~s}$ and $15 \mathrm{~s}$, respectively. This might be due to the swelling and wicking mechanism (drawing water through capillary action) of water penetration in tablets containing SSG. ${ }^{25}$
Wetting time is closely related to the inner core density and hardness of the tablet. The wetting time of the prepared tablets was found to be between $12 \mathrm{~s}$ and $32 \mathrm{~s}$. The wetting time of formulations $\mathrm{CPX}_{5}$ and $\mathrm{CPX}_{4}$ was $12 \mathrm{~s}$ and $19 \mathrm{~s}$, respectively. It has been found that with an increase in the concentration of superdisintegrants, the wetting time is rapidly decreased. Figure 4 presents the relationship between disintegration time and wetting time of different RDTs. The relationship between wetting time and water absorption ratio of different RDTs is presented in Fig. 5.

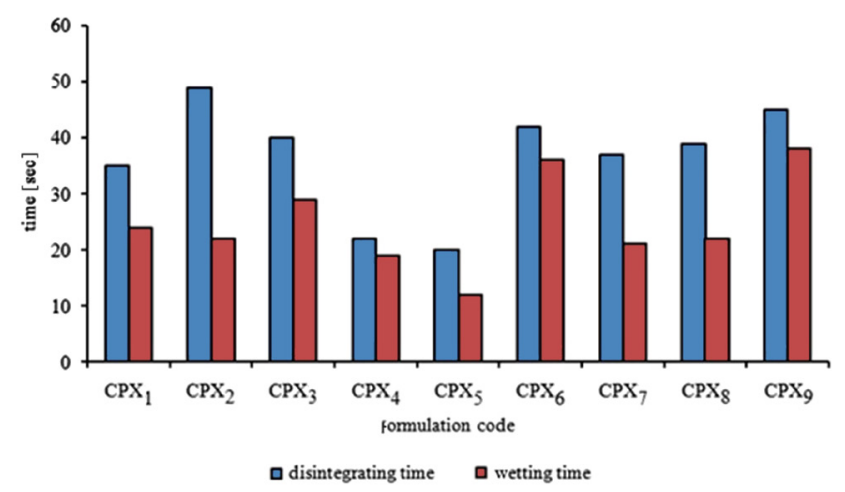

Fig. 4. Relationship between wetting time and disintegration time of different rapidly disintegrating tablets (RDTs) (formulation $\mathrm{CPX}_{1}-\mathrm{CPX}_{9}$ )

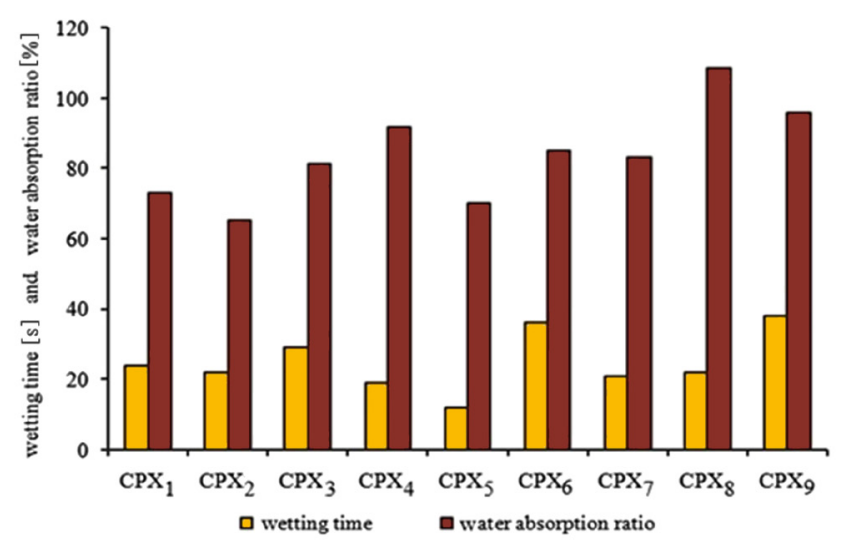

Fig. 5. Relationship between wetting time and water absorption ratio of different rapidly disintegrating tablets (RDTs) (formulation $\mathrm{CPX}_{1}-\mathrm{CPX}_{9}$ )

Table 3. Post-compression parameter of prepared rapidly disintegrating tablets (RDTs)

\begin{tabular}{|c|c|c|c|c|c|}
\hline $\begin{array}{l}\text { Formulation } \\
\text { code }\end{array}$ & $\begin{array}{l}\text { Uniformity of weight } \\
\text { [mg/tablet] }\end{array}$ & $\begin{array}{l}\text { Thickness } \\
{[\mathrm{mm}] \pm S \mathrm{SD}}\end{array}$ & $\begin{array}{l}\text { Hardness } \\
{\left[\mathrm{kg} / \mathrm{cm}^{2}\right]}\end{array}$ & $\begin{array}{c}\text { Water absorption ratio } \\
{[\%]}\end{array}$ & $\begin{array}{l}\text { Friability } \\
{[\%]}\end{array}$ \\
\hline $\mathrm{CPX}_{1}$ & $198.51 \pm 0.04$ & $2.69 \pm 0.23$ & $3.40 \pm 0.32$ & $73.00 \pm 0.17$ & $0.36 \pm 0.40$ \\
\hline $\mathrm{CPX}_{2}$ & $200.41 \pm 0.12$ & $2.00 \pm 0.56$ & $3.90 \pm 0.06$ & $65.33 \pm 0.45$ & $0.26 \pm 0.21$ \\
\hline $\mathrm{CPX}_{3}$ & $199.01 \pm 0.22$ & $2.34 \pm 0.04$ & $2.90 \pm 0.03$ & $81.16 \pm 0.62$ & $0.30 \pm 0.33$ \\
\hline $\mathrm{CPX}_{4}$ & $200.03 \pm 0.30$ & $2.43 \pm 0.08$ & $3.80 \pm 0.02$ & $91.66 \pm 0.98$ & $0.34 \pm 0.26$ \\
\hline $\mathrm{CPX}_{5}$ & $200.01 \pm 0.16$ & $2.83 \pm 0.04$ & $3.16 \pm 0.08$ & $70.08 \pm 0.72$ & $0.25 \pm 0.11$ \\
\hline CPX6 & $198.40 \pm 0.01$ & $2.16 \pm 0.07$ & $2.90 \pm 0.04$ & $85.00 \pm 0.09$ & $0.26 \pm 0.18$ \\
\hline $\mathrm{CPX}_{7}$ & $199.03 \pm 0.21$ & $2.29 \pm 0.02$ & $3.12 \pm 0.02$ & $83.06 \pm 0.05$ & $0.29 \pm 0.38$ \\
\hline $\mathrm{CPX}_{8}$ & $200.04 \pm 0.12$ & $2.99 \pm 0.05$ & $3.20 \pm 0.12$ & $108.33 \pm 0.68$ & $0.34 \pm 0.26$ \\
\hline $\mathrm{CPX}_{9}$ & $200.23 \pm 0.62$ & $2.63 \pm 0.61$ & $2.30 \pm 0.40$ & $95.83 \pm 0.91$ & $0.37 \pm 0.33$ \\
\hline
\end{tabular}

Data presented as mean \pm standard deviation $(\mathrm{SD}) ; \mathrm{n}=3$. 


\section{Water absorption ratio}

The water absorption ratio is used to determine the amount of water absorbed by the tablet. The water absorption ratio of the RDTs was observed in the range from $65 \pm 0.45 \%$ to $108.33 \pm 0.68 \%$. Formulated batches of tablets $\mathrm{CPX}_{4}, \mathrm{CPX}_{8}$ and $\mathrm{CPX}_{9}$ absorbed more than $90 \%$ of the water, while the other batches had less capacity to absorb water (Table 3 ). The results indicated that SSG and CP had higher water absorption ratios when compared to the CMS.

\section{Friability}

The friability of the prepared tablets was found to between $0.26 \pm 0.21 \%$ and $0.86 \pm 0.40 \%$, which is within the acceptable limit of less than $1 \%$ (Table 3 ). The formulated tablets had good mechanical strength and can be handled without excessive care.

\section{X-ray diffraction}

The tablets developed using the drug- $\beta-C D$ complex did not show many characteristic peaks of the pure drug, indicating a molecular dispersion of the drug within the polymer matrix in amorphous form (Fig. 6).

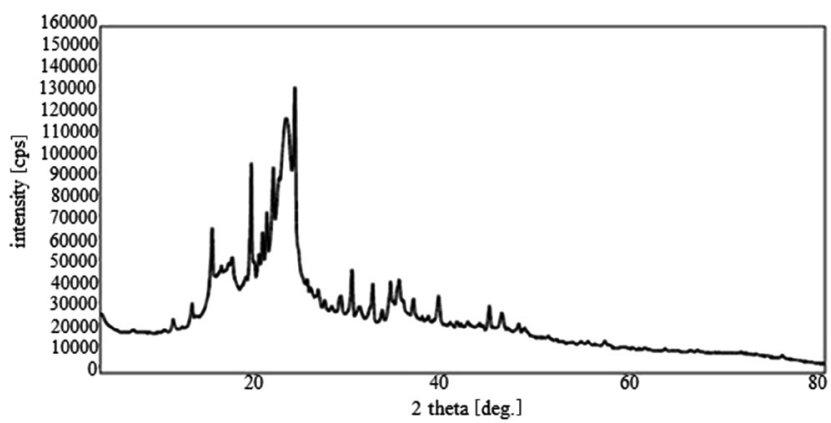

Fig. 6. X-ray diffraction patterns of best selected rapidly disintegrating tablet (RDT) (formulation $\mathrm{CPX}_{5}$ )

\section{In vitro dissolution studies}

Dissolution studies were conducted for all the formulations given in the USP dissolution apparatus II using phosphate buffer ( $\mathrm{pH}$ 6.8). It had been observed from the drug release profile that $>90 \%$ of the drug was released within $10 \mathrm{~min}$; drug release profiles are shown in Fig. 7. As the concentration of superdisintegrants increases, the release of the drug also increases. The dissolution study results suggested that sodium starch glycolate acted as the best superdisintegrant among the investigated superdisintegrants.

From Table 4, it is evident that the drug release from the developed RDTs followed first order release kinetics.

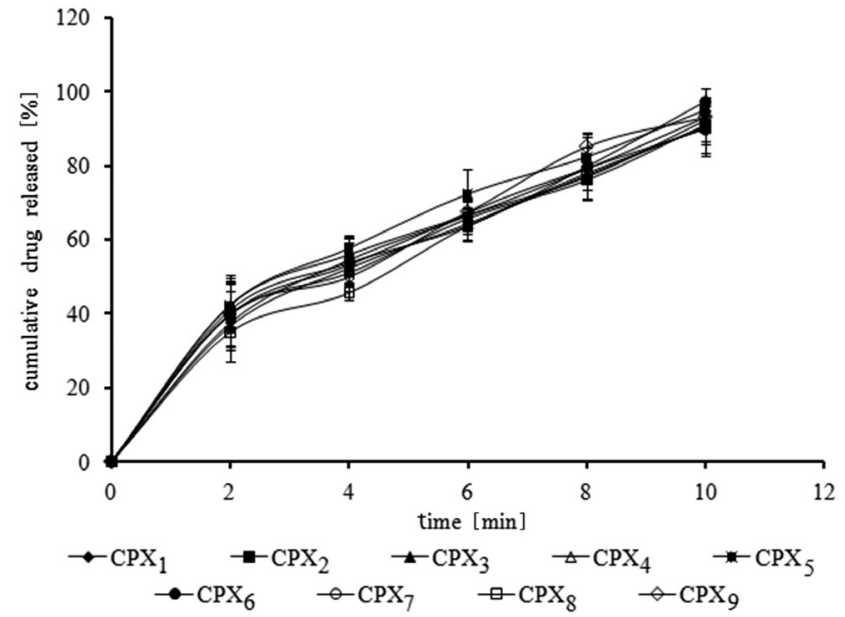

Fig. 7. In vitro release rate profile of levocetirizine from rapidly disintegrating tablets (RDTs) (formulation $\mathrm{CPX}_{1}-\mathrm{CPX}_{9}$ ) in phosphate buffer solution (pH 6.8) at $37 \pm 0.2^{\circ} \mathrm{C}$ (mean \pm standard deviation $(\mathrm{SD}), \mathrm{n}=3$ )

\begin{tabular}{|c|c|c|}
\multicolumn{3}{|c|}{ Table 4. Release kinetic data of formulation $\left(P X_{1}-\left(P X_{9}\right)\right.$} \\
\hline Formulation code & $\begin{array}{c}\text { Zero order } \\
r^{2}\end{array}$ & $\begin{array}{c}\text { First order } \\
r^{2}\end{array}$ \\
CPX $_{1}$ & 0.923 & 0.926 \\
$\mathrm{CPX}_{2}$ & 0.934 & 0.939 \\
$\mathrm{CPX}_{3}$ & 0.944 & 0.960 \\
$\mathrm{CPX}_{4}$ & 0.913 & 0.927 \\
$\mathrm{CPX}_{5}$ & 0.919 & 0.935 \\
$\mathrm{CPX}_{6}$ & 0.839 & 0.912 \\
$\mathrm{CPX}_{7}$ & 0.933 & 0.971 \\
$\mathrm{CPX}_{8}$ & 0.940 & 0.951 \\
$\mathrm{CPX}_{9}$ & 0.939 & 0.958 \\
\hline
\end{tabular}

\section{Conclusions}

The prepared RDTs had ideal physical properties such as uniform weight, satisfactory hardness, better friability strength, less disintegration time, and rapid release profiles to be used as a RDDDS for the anti-allergic drug. In vitro release of levocetirizine followed first order kinetics. The prepared tablets can be used in dysphagia conditions.

\section{References}

1. Comoglu T, Unal B. Preparation and evaluation of an orally fast disintegrating tablet formulation containing a hydrophobic drug. Pharm Dev Technol. 2015;20(1):60-64.

2. Gohel M, Patel M, Amin A, Agrawal R, Dave R, Bariya N. Formulation design and optimization of mouth dissolve tablets of nimesulide using vacuum drying technique. AAPS PharmSciTech. 2004;5(3):e36.

3. Awasthi R, Sharma S, Dua K, Kulkarni GT. Formulation of fast disintegrating drug delivery system. J Chronother Drug Deliv. 2013;4(1):15-18.

4. Liang AC, Chen LH. Fast-dissolving intraoral drug delivery systems. Expert Opin Ther Patents. 2001;11(6):981-986.

5. Morita Y, Tsusima Y, Yasui M, Termoz R, Ajioka J, Takayama K. Evaluation of disintegration time of rapidly disintegrating tablets via a novel method utilizing a CCD camera. Chem Pharm Bull. 2002;50(9):1181-1186.

6. Fu Y, Yang S, Jeong SH, Kimura S, Park K. Orally fast disintegrating tablets. Developments technologies, taste-masking and clinical studies. Crit Rev Ther Drug Carrier Syst. 2004;21(6):433-475. 
7. Bircan $Y$, Comoglu T. Formulation technologies of orally fast disintegrating tablets. J Pharm Marmara Univ. 2012;2(16):77-81.

8. Chang RK, Guo X, Burnside BA, Couch RA. Fast dissolving tablets. Pharm Technol. 2000;24:52-58.

9. Sharma D. Formulation development and evaluation of fast disintegrating tablets of salbutamol sulphate for respiratory disorders. ISRN Pharm. 2013;2013:674507.

10. Goel H, Rai P, Rana V, Tiwary AK. Orally disintegrating systems: Innovations in formulation and technology. Recent Pat Drug Deliv Formul. 2008;2(3):258-274.

11. Parkash V, Maan S, Deepika, Yadav SK, Hemlata, Jogpal V. Fast disintegrating tablets: Opportunity in drug delivery system. J Adv Pharm Technol Res. 2011;2(4):223-235.

12. Madan JR, Kamate VJ, Awasthi R, Dua K. Formulation, characterization and in-vitro evaluation of fast dissolving tablets containing gliclazide hydrotropic solid dispersions. Recent Pat Drug Deliv Formul. 2017;11(2):147-154.

13. Cirri M, Rangoni C, Maestrelli F, Corti G, Mura P. Development of fast dissolving tablets of flurbiprofen-cyclodextrin complexes. Drug Dev Ind Pharm. 2005;31(7):697-707.

14. Dua K, Pabreja K, Ramana MV, Lather V. Dissolution behavior of $\beta$-cyclodextrin molecular inclusion complexes of aceclofenac. J Pharm Bioallied Sci. 2011;3(3):417-425.

15. Dua K, Ramana MV, Sara UV, et al. Investigation of enhancement of solubility of norfloxacin beta-cyclodextrin in presence of acidic solubilizing additives. Curr Drug Deliv. 2007;4(1):21-25.

16. Malipeddi VR, Dua K, Awasthi R. Development and characterization of solid dispersion-microsphere controlled release system for poorly water-soluble drug. Drug Deliv Trans/ Res. 2016;6(5):540-550.

17. Gorajana A, Rajendran A, Yew LM, Dua K. Preparation and characterization of cefuroxime axetil solid dispersions using hydrophilic carriers. Int J Pharm Investig. 2015;5(3):171-178.

18. Lyn LY, Sze HW, Rajendran A, Adinarayana G, Dua K, Garg S. Crystal modifications and dissolution rate of piroxicam. Acta Pharm. 2011;61(4):391-402.

19. Awasthi R, Kulkarni GT. Development and characterization of amoxicillin loaded floating microballoons for the treatment of Helicobacter pylori induced gastric ulcer. Asian J Pharm Sci. 2013;8:174-180.

20. Dhiman N, Awasthi R, Jindal S, Khatri S, Dua K. Development of bilayer tablets with modified release of selected incompatible drugs. Polim Med. 2016;46(1):5-15.

21. Comoglu T. Formulation and evaluation of carbamazepine fast disintegrating tablets. Pharm Ind. 2010;72(1):150-158.

22. Sunada $\mathrm{H}, \mathrm{Bi}$ Y. Preparation, evaluation and optimization of rapidly disintegrating tablets. Powder Technol. 2002;122(2-3):188-198.

23. Lai F, Pini E, Angioni G, et al. Nanocrystals as tool to improve piroxicam dissolution rate in novel orally disintegrating tablets. Eur $\mathrm{J}$ Pharm Biopharm. 2011;79(3):552-558.

24. United States Pharmacopeia, $24^{\text {th }}$ revision, Asian Edition. United States Pharmacopoeial Convention, Inc.: Rockville, MD; 2000.

25. Desai PM, Liew CV, Heng PW. Review of disintegrants and the disintegration phenomena. J Pharm Sci. 2016;105(9):2545-2555. 